\title{
E-Learning as an Important Component in "Blended Learning” in School Development Projects in Norway
}

\author{
doi:10.3991/ijac.v6i1.2299 \\ Ann Margareth Aasen \\ Hedmark Universtity College, Hamar, Norway
}

\begin{abstract}
E-learning is an important component in "blended learning" in all of Centre of the Study of Educational Practice `s (SePU) projects and is used for additional education and development of competences. Blended learning is defined as learning facilitated by the effective combination of different modes of delivery, models of teaching, styles of learning, and based on transparent communication among all parties involved in development competences. All projects are based on an understanding of learning as a process where you learn by collaborating with others. Collaboration is to be distinguished from cooperation. In cooperation, partners split the work, solve sub-tasks individually, and then assemble the partial results into the final output. In collaboration, partners do the work together. Research indicates schools with good cooperative cultures are most likely to succeed, both during and after the project period. This article will examine how e-learning, as one of many principles from "blended learning," can contribute to competence development through collaborative learning and present some evaluation results from a project that has been employing the "blended learning" principles.
\end{abstract}

Index Terms - blended learning, collaborative learning in teams, competence- and school development, e-learning.

\section{INTRODUCTION}

Today, every school conducts some kind of competence development work, although with varying results. Research shows that it is difficult to implement a program or a development project in schools with long-lasting results [1]. There are significant differences among schools with respect to their will to change, as well as how they plan and carry out their development projects [2]. Encouraging teachers to further develop their teaching practice is also challenging [3].

Today we know quite a bit about what it takes to achieve progressive results from a development project [4]. The goal of developmental work in school is to change and develop teachers' classroom practices to give students the best possible learning outcomes, both academically and socially [5]. Teachers need platforms for reflection, learning, dialogue, and sharing of knowledge to develop their own competences and contribute to the positive development of schools. And schools need tools and methods to create a good environment for learning and competence [6]. An implemental strategy that address these needs, is "blended learning." "Blended learning" focuses on different approaches in educating professionals. Employing several approaches increases the probabil- ity of reaching a greater audience. The Centre of the Study of Educational Practice (SePU) has positive experiences using principals of "blended learning" in its projects. The different approach methods employed in our projects consist of training courses, e-learning with group tasks and external evaluation, group supervision, and development of individual practice. All these activities can be arranged and carried out at teachers' workplace.

This article focuses on how e-learning, as one of many components within "blended learning," may contribute to competence development, both for the teachers in collaborative reflection groups, as well as for other school staff members. Furthermore, this article presents an evaluation of a project that is currently applying the principles of "blended learning."

\section{KNOWLEDGE OF DEVELOPMENTAL WORK IN SCHOOLS}

The challenge we face is how to apply the wealth of knowledge to benefit schools and classrooms [4]. For example, Hattie [7] indicates a significant link between student learning outcomes and how competent teachers are with regard to teaching structure, feedback, and learning expectations; the most influential factor on student learning outcomes is the teacher. Hattie maintains that too much emphasis has been placed on implementing on an institutional level, rather than focusing on what really matters - the teacher. He concludes that the potential for improvement lies behind the classroom door during the actual teaching, classroom management and in the relationship between students and teachers.

Fullan [5] claims even though the idea and quality of any particular development program accounts for $25 \%$ of the final result, the remaining $75 \%$ depends on work. This means the results are greatly dependent on the actual work carried out in schools. Several studies document good results in schools that manage to change the teachers' perspectives away from looking for flaws in students to focusing on what they can do with their own teaching practice to promote their students' learning potential [8] [9].

Such changes of perspective require reflection and learning, combined with dialogue and sharing of knowledge. Teachers' collaboration is vital for this work. SePU organizes its projects based on a social constructive understanding of learning, where learning is understood as a process best accomplished through collaboration. Learning through collaboration may consist not only of sharing of experiences, but also of gaining and reflecting over new knowledge together. All school developmental 
and pedagogical practice should be based on knowledge informed through research, than habits and beliefs [8].

A school culture where collaboration and group discussions are prioritized does not develop on its own, but results from a process where teachers collaborate, reflect, and work together towards the same goal. A culture of collaboration strengthens schools' abilities to make decisions and promotes a sense of professionalism among colleagues [10]. A collaborative school culture is not developed straightaway, but needs constant maintenance and development. If a school's culture does not continue to develop, earlier pedagogical practice will soon be reestablished [4]. That means the school will fall back into its old habits in all probability, which are unwanted. SePU strives to implement strategies in developing collaborative cultures in its projects, by use of e-learning.

\section{E-LEARNING AS AN IMPORTANT PART OF EDUCATION}

Change and development projects can be arranged in many ways. One of the challenges with school development concerns how to effectively improve teacher competence. Participation in external courses is often costly in terms of time, finances, and organization. Due to such constraints, it is better to organize and carry out most of the pedagogical development within the framework available at teachers' workplaces. Through the principles of "blended learning," all methods for knowledge development can be carried out at the participating schools, such that the entire pedagogical staff can participate in the same project.

SePU bases its school development projects on the research-based knowledge presented in Part II of this article. "Blended learning" involves both training courses and external guidance, but the main focus of this article is the use of e-learning, which takes place in collaborative groups with the goal of increasing competence and developing practical skills.

Every school that participates in our development projects must spend a minimum of one hour every other week working in groups. These groups consist of 5-7 teachers, preferably not from already existing teams. All groups have a group leader. This role is very important, and the school leader should therefore delegate responsibilities carefully [11].[12].

This work is intended to lead to a reflective and analytical approach to individual practice. The goal is to change and develop teaching practices with the intention of improving student achievement. Good communication and dialog within groups are therefore very important, as is the promotion of research-based knowledge. To be able to discuss and make plans with colleagues and others in professional terms, one has to have a certain degree of competence that can be gained with the help of relevant literature. Teacher competence is raised through training courses and e-learning modules. Each e-learning module provides guidelines for how the work of the teacher groups will be conducted. The constraints are related to both the disposal of the meeting time and topics for discussion. I'll give some examples of what is in these guidelines.

Every e-learning module focuses on a given topic introduced by a text written by researchers at SePU. The text includes questions for reflection as well as a final assign- ment. The teachers are supposed to read and discuss the text in groups, comparing it to their own practice. The group then completes the written assignment, no longer than three pages. These assignments vary. Some are straightforward reflective tasks, where teachers discuss their own teaching practices in light of relevant theory. Other assignments require classroom trials. For example, teachers may try out various suggested approaches in their own classrooms. The assignment then asks teachers to reflect and analyze their actual classroom practice. The group assignments are sent directly to a SePU's employee by e-mail or are uploaded to the school's Learning Management System (e.g. itslearning or Fronter). The researcher at SePU responds to the group within two weeks after receiving the assignment.

Two group meetings are suggested for those modules that do not require classroom trials, whereas the practical modules require more than two group sessions. All development projects link research with the development of individual practice. The number of modules per year also varies, depending on themes and organization. Normally, there will be two to four modules a year.

Evaluation of other SePU developmental projects, indicate there are significant variations how teachers read and apply theory in the absence of guidelines. There are also differences in how constructive the different group meetings are [11] [12]. By providing guidelines, like time in the group meetings to read and discuss texts followed by required written work, increases the likelihood of teachers raise their competence. Moreover, the group discussions are less likely to digress from the topics at hand.

Effective leaders are decisive for well-functioning group [12]. Group leaders receive special training at the start of the development project. This type of competence training is also organized through e-learning. In addition to specialized education, group leaders meet with school leaders 3-4 times a year. The group leaders thus function as a link between the teachers' group discussions and school leaders. School leaders play an important role in the development work. They lead and support the teachers. Consequently, school leaders require knowledge about leadership during change and a good understanding of how they can support individuals and groups to raise competence. School leaders need to arrange opportunities for teachers to experience success in their work, like the teachers arrange for students to experience success in theirs [13]. Some of the projects have established network groups to help school leaders in their roles. School leaders are provided support through e-learning. Themes are mainly linked to school development and school leaders' role in this work. The assignments may deal with reflection over challenges within schools and how to approach these problems. Or the assignments can deal with how school leaders may support and follow up with teachers through the efforts that are carried out by the teachers groups. School leaders meet approximately six times a year.

The final group that is offered e-learning programs are school assistants. In Norway, most students in the first to third grades are in before- or afterschool programs. Such activities are provided through the fourth grade, but most students stop participating in the programs after third grade. Because the programs do not specifically offer any pedagogical programs, most of the responsible staff members are not educated teachers. The same people 
often work as classroom assistants during the school day. Assistants, who often have no more than a high school degree, are responsible for more than $40 \%$ of the special education needs in Norwegian schools. The assistants do not have any hours in their workday allocated for planning, which makes collaborating with teachers difficult. It is important to include these staff members in schools' developmental projects. SePU has prepared unique elearning modules for this group of school assistants to improve their competence and develop their own practice.

\section{RESULT-ORIENTED SCHOOL DEVELOPMENT}

For schools to achieve the best possible outcome from school development, it is necessary to evaluate the effectiveness of the project, both when it is ongoing and after it has ended [14]. Surveys therefore comprise a central element in several of our development projects. In these projects, the schools complete two surveys in the course of the project period. Each school's results are viewed in relation to the average results of all schools participating at the same time. In such a way, schools will gain a clear picture of their own results compared to the average of the other schools. The focus of the first survey, conducted at the beginning of the project, is to discover whether any one particular area is especially strong or weak, and where measures should be targeted. The second survey, carried out two years later, focuses on change and development. How have things changed from the first survey? Have we reached our aims? Are there other areas that require attention?

We have experienced that many schools do not apply the information gained from statistical results in any systematic way. We have tried to meet this problem with the e-learning modules for school leaders. Not only do these modules teach participants how to analyze and apply results, they also commit school leaders to make specific plans to meet the challenges in their individual schools. According to Doufour and Marzano [8], three conditions need to be met by schools and teachers to improve results:

- To have good strategies for maximum learning outcome for all students based on their own abilities.

- School leaders and teachers have to work together to support all students' learning.

- Both school leaders and teachers need to establish a result-oriented culture to discover whether teaching is effective in terms of student outcomes.

Underlying these three conditions is an understanding the correlation between students' learning outcomes and teachers' practice. This means the information from assessment and evaluation needs to be used to further develop teachers' practice. The potential for development offered by our project lies in equipping teachers with the ability to understand information from quantitative results, in addition to being able to analyze challenges in their own teaching practice.

\section{EVALUATION OF A “BLENDED LEARNING” PROJECT}

This article will be closed with results from an evaluation [15] of a Danish project where they use all principles from "blended learning" in the way outlined here. Competence-raising projects are aimed at school leaders, teachers, and group leaders. This project was carried out from
2008 to 2011 where 158 schools participated. Roughly 30,000 students and 5,500 teachers answered the survey, composed of three questionnaires: One for fourth to ninth grade students, one for their class teachers, and one for all of the schools' teachers. The average development from the first survey (T1) to the second survey (T2) will be presented on a 500-point scale. In this scale, the results from T1 are defined as 500, against which the results of T2 are compared.

It is difficult to measure impact. Hattie [7] explains that changes greater than 20 points are small changes, but nevertheless large enough to be significant. Differences between the two surveys greater than 60 points are considered very significant. Hattie's figures, however, are intended to measure degree of academic achievement, and can therefore only be used as guides in this comparison.

Figure 1 shows that the teachers at the 158 schools developed an improved collaborative environment during the project period. They became more satisfied with their own work situation, experienced better relationships with their students, handled behavioural problems more effectively, and their classes became calmer.

As Figure 2 shows, teachers' work in their groups have had a positive effect on the students. Even though the changes are small, they are in the right direction.

Contact teachers were also asked about each student in their classes, and Figure 3 presents a general overview of their responses. Here we see that teachers noted positive tendencies with respect to their students' social skills.

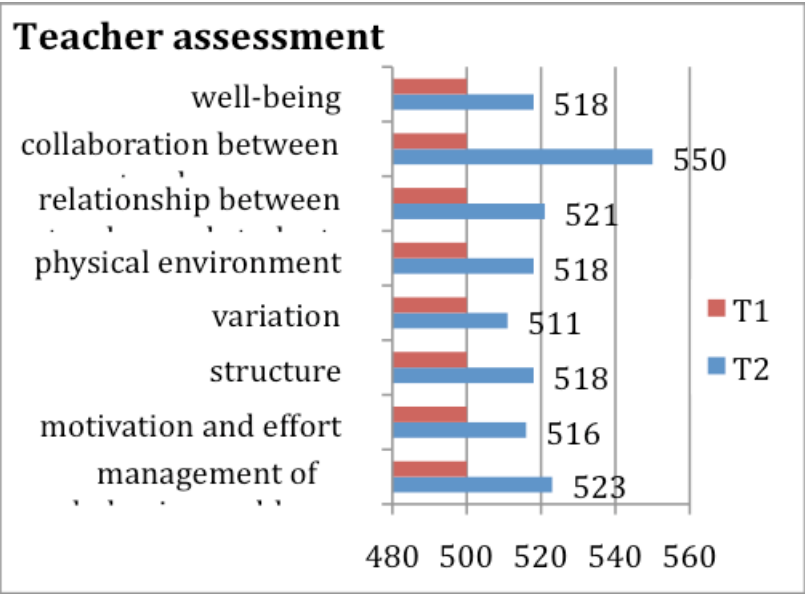

Figure 1. The schools' development from T1 to T2, teacher evaluations.

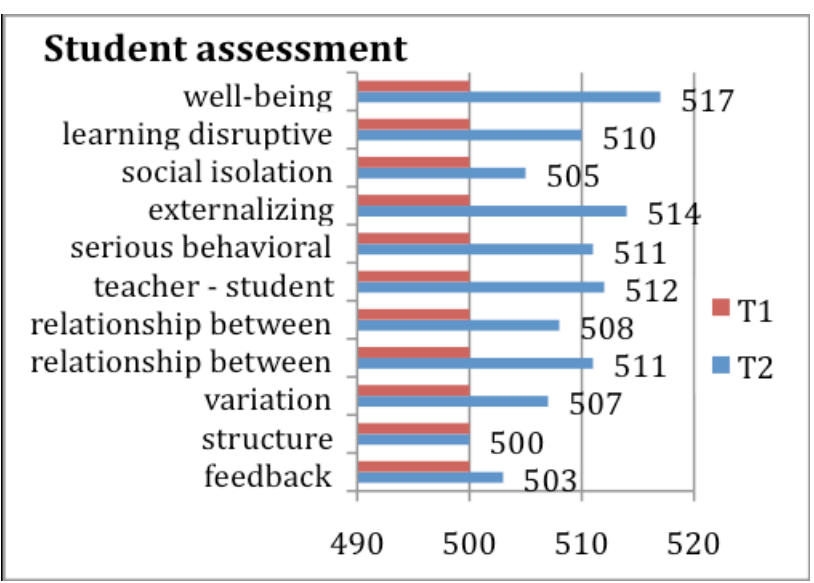

Figure 2. The schools' development from T1 to T2, student assessment 


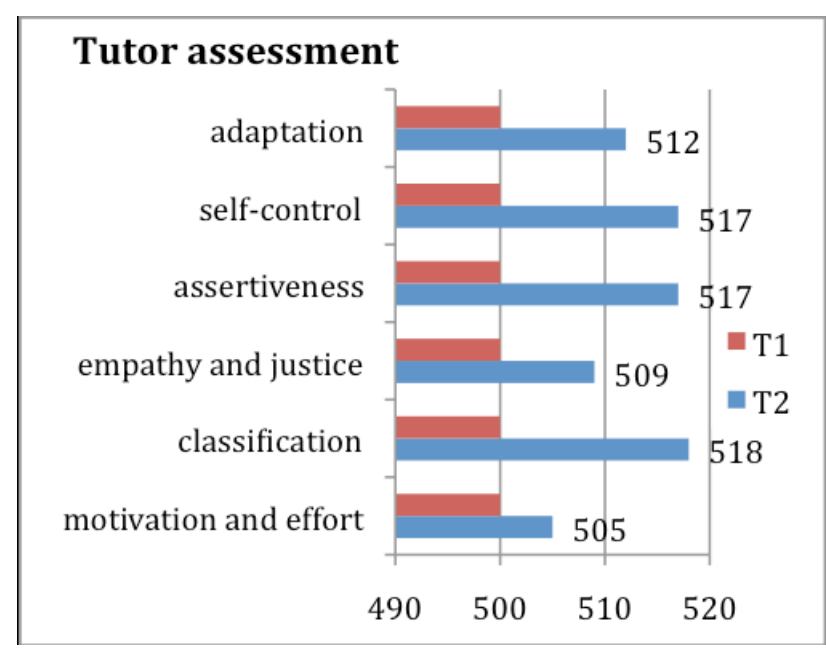

Figure 3. The schools' development from T1 to T2, contact teacher assessment.

In sum, the learning and teaching environments seem to have improved for all informants by the time of the second survey. As a result, it can be argued that the use of "blended learning" in these schools helped provide students better conditions to succeed in school. Although there are few areas that show more than minor changes, the overall trend shows significant positive development in almost all areas. Systematic progress in many areas may be considered just as positive as a great impact in a single area [15].

Only the average of results is presented here, meaning that some schools experienced more positive changes than others. Such differences are frequently related to the degree of effort placed into the development project by the individual schools [11] [12].

\section{SUMMARY AND CONCLUSION}

This article has had two intentions. The first has been to examine how e-learning, as one of many principles from "blended learning," can contribute to competence development through collaborative learning. The second aim has been to present the evaluation results from a project that has been employing the "blended learning" principles.

SePU has gained a great of experience in applying different approaches to school development projects. Such development projects affect all teachers and school leaders at a school, not just a selection of classes and teams. School-wide projects require a cooperative culture, characterized by staff members who share an understanding of the challenges the school faces and meet them together. Research indicates schools with good cooperative cultures are most likely to succeed, both during and after the project period [16]. During the hectic everyday life of teachers, there is little time to sit down and discuss the fundamental elements of the profession - pedagogy. Hargreaves et al. [17] write that when teachers are given the opportunity to study their profession and challenges in light of relevant research with colleagues, they rediscover the meaning and joy of learning, as well as the personal and professional motivations that once led them to choose the teaching profession. In order to work effectively, collaboration needs to be planned in the teaching environment using tools and resources that contribute to increased participation. SePU's e-learning tool structures teachers groups for professional competence raising and personal skill development. E-learning as a tool also seems to function well for training of other groups.

E-learning is also an effective means of reaching a large audience. At SePU, eight researchers have assisted more than 150 teacher groups during the 2011-2012 school year. These eight people have been working with competence development by writing texts for discussion and also responding to assignments from approximately 900 teachers. This figure does not even include school leaders and assistants. Moreover, teacher groups have had a minimum one supervisory session per year, carried out in their respective workplaces by the same eight researchers. Without e-learning as a tool, SePU have not the capacity to engage in development work in as many schools as we can today.

The most important goal for school development is further developing already established practices for the entire school to improve student achievement. E-learning makes no change by itself. The most important change lies within the participants. The main aim of our projects is making practice-related competence development, where collaboration in teams plays a central part. Research shows that one-shot guest instructors who come and go have very little impact on teachers' work. If learning is to be understood as lasting change, teachers need time to work and focus on phenomena, questions and content and continuous support for their efforts [18]. E-learning is a good way to support work in teachers' groups and ensure progression. We have experienced that the module texts and assignments through e-learning lead to greater commitment to the group work and afford us the opportunity to support, supervised, and correct using this process. Elearning is also less expensive than traditional classroom instruction. In addition, many expenses - booking facilities, travel costs for employees, plus employee time away from the job - are greatly reduced.

The results from the survey show positive changes for the schools that have worked according to the principles from "blended learning". This indicates that this way of working is effective, especially if the school is committed to its implementation.

\section{REFERENCES}

[1] U.V. Midthassel, E. Bru, S. K Ertesvåg and E. Roland, Tidlig intervensjon og systemrettet arbeid for et godt læringsmiljø. Oslo: Universitetsforlaget, 2011

[2] P. M. Short, J. T. Greer, W.M. Melvin, Creating empowered schools: Lesson in change. Journal of Education Administration, 32 (4), 38-52, 2001 http://dx.doi.org/10.1108/09578239410069106

[3] P. Haug, Resultat frå evalueringa av Reform 97. Oslo: Noregs forskningsråd

[4] T. Nordahl, Læringsmiljø og pedagogisk analyse: en beskrivelse av evaluering av LP-modellen. Oslo: NOVA, 2005-19

[5] M. G. Fullan, "Leading in a culture of change”, San Francisco: Jossey-Bass, 2001.

[6] R. Tobiassen, Å lære lærere å lære - kompetanseutvikling gjennom narrative orientert aksjonslæring. Utdanning for utvikling av skolen. Oslo: Gyldendal akademiske, 2006

[7] J. Hattie, Visible learning: a synthesis of over 800 meta-analyses relating to achievement. London: Routledge, 2009

[8] R. Dufour \& R. J. Marzano, Learning of Leaders. Bloomington: Solution Tree Press, 2011

[9] B. Levin, How To Change 5000 Schools: a practical and positive approach for lea ding Change at every level. Cambridge, Mass: Harvard Education Press, 2008 
PAPER

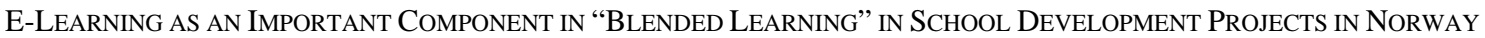

[10] A. Hargreaves, Lererarbeid og skolekultur: lereryrkets forandring i en postmoderne tid. Oslo: Ad notam Gyldendal, 1996

[11] .M. Aasen \& A. K. Kostøl, "Det gjelder å holde ut": en kvalitativ og kvantitativ evaluering av pilotprosjektet LP-modellen $i$ videregående opplering 2008-2010 (LPVGO) (Vol. nr. 12-2011). Elverum: Høgskolen, 2011

[12] A.M. Aasen \& A. K. Kostøl, "Vi ser at det funker": en kvalitativ og kvantitativ evaluering av arbeidet med LP-modellen 2008-2010 (LP3) (Vol. nr. 5-2011). Elverum: Høgskolen.

[13] B. Levin, How To Change 5000 Schools: a practical and positive approach for lea ding Change at every level. Cambridge, Mass: Harvard Education Press, 2008

[14] A. Hargreaves, Larerarbeid og skolekultur: lareryrkets forandring i en postmoderne tid. Oslo: Ad notam Gyldendal, 1996

[15] A.M. Aasen \& A. K. Kostøl, "Det gjelder å holde ut": en kvalitativ og kvantitativ evaluering av pilotprosjektet LP-modellen i videregående opplaring 2008-2010 (LPVGO) (Vol. nr. 122011). Elverum: Høgskolen, 2011

[16] A.M. Aasen \& A. K. Kostøl, "Vi ser at det funker": en kvalitativ og kvantitativ evaluering av arbeidet med LP-modellen 2008-2010 (LP3) (Vol. nr. 5-2011). Elverum: Høgskolen., 2011
[17] A. Hargreaves, D. Shirley \& E. Fredheim. Den fjerde vei: en inspirasjon til endring i skolen. Oslo: Gyldendal akademisk, 2012

[18] L. M. Desimone, Improving impact studies of teachers’ professional development: toward better conceptualizations and measures. Educational Researcher, 38(3), 181-199 http://dx.doi.org/ $\underline{10.3102 / 0013189 \times 08331140}$

\section{AUTHORS}

Ann Margareth Aasen, Master in Pedagogic, associate professor at the Centre of the Study of Educational Practice (SePU), Hedmark University College, Skolegata 12, Hamar, Norway (ann.aasen@hihm.no).

This article is an extended and modified version of a paper presented at the the International Conference on E-learning in the Workplace 2012 (ICELW'12), held in June 2012, at Columbia University in New York, NY, USA. Manuscript received 27th of April 2012. Published as resubmitted by the author 11 February 2013. 